\title{
Constitution without constitutionalism: interrogating the Africa experience
}

\begin{abstract}
The work focuses on constitution without constitutionalism and the Africa experience. The idea of constitutionalism project two alternatives: constitution without constitutionalism and constitution with constitutionalism. Every political system has a constitution whether it is a constitutional system or not. But in Africa, constitution without constitutionalism is well instituted in governance; that has being responsible for her inability to progress. Any constitution without constitutionalism will definitely create a disconnection between the state and the citizen as it often does, making it increasingly difficult for the citizens to rely on the state. Thus, the society becomes an arena of various conflicts and promotion of common good is thereby sacrificed. This work trace the development of constitution without constitutionalism and the associated problems in Africa and concluded that if African is to make any meaningful progress in governance there is the need for Africa to adopt constitution with constitutionalism because that is the only alternative option for progress in governance and best way to meet the common good of her people.
\end{abstract}

Keywords: constitution, constitutionalism, community, governance, articulates, aggregates, ideological pronouncements, legal regulations, human society, political theory, international community
Volume 2 Issue 5 - 2018

\section{Aborisade Olasunkanmi \\ Ladoke Akintola University of Technology, Nigeria}

Correspondence: Aborisade Olasunkanmi, Ladoke Akintola University of Technology, Ogbomoso, P.M.B 4000 Ogbomoso, Nigeria, Tel +234-803-800-364,

Email aborisaderose@yahoo.com, Omoboy4I@gmail.com

Received: November 04, 2017| Published: September 24, 2018

\section{Introduction}

A constitution, being the fundamental system of the law in any sovereign state. It provides definition for the citizenship an institution. It prescribes rights, responsibilities, obligations and duties. It distributes, secures and limits authority and powers, aggregates and articulates aspirations and interests and; outlines procedures for actions, and interactions and; sanctions default. ${ }^{1}$ Constitution is the most fundamental system of law in the state; the ultimate authority in the state. De Smith \& Brazir ${ }^{2}$ state that constitutions are primarily about political authority and the location of power, conferment, distribution, exercise and limitation of authority and power among the agents of a state. They are concerned with matters of procedure as well as substance. They also include explicit guarantee of the rights and freedom of individual as well as incorporate ideological pronouncements, that is principles by which the state ought to be guided or to which it ought to aspire and statements of the citizens' duties. The constitution states and limits the powers of the organs of government as well as regulates the behaviors of the citizens, be it in relation to them or to the state. Thus, one could reasonably contend that the constitution is a logical instrument of state as well as social control and regulation baring a higher status. It is said to have a higher status in the sense that, it is supposed to be higher than any other body of legal regulations in human society.

Constitutionalism also is a form of political thought and action that seeks to prevent tyranny and guarantees the liberty and rights of individuals on which free society depends. ${ }^{3}$ It is based on the idea that government can and should be limited in its powers, and that its authority depends on enforcing these limitations. In this regard, constitutionalism is a political theory concerned with the architectural structure and basic values of the society and the government. It aims to make the world comprehensible and, to some extent, controllable. Historically, it is preoccupied with the problem of power, particularly the power of those who would rule, especially when that rule might be arbitrary" ${ }^{4}$ Constitutionalism, then, could be understood as the expression of a set of abstract moral principles. ${ }^{5}$ It suggests certain principles of right and justice which are entitled to prevail on the basis of their own intrinsic excellence, altogether regardless of the attitude of those who wield the physical resources of the community.

\section{Constitution and constitutionalism}

There is a distinction between a government with a constitution and constitutionalism and a government with constitution without constitutionalism. Every political system has a constitution whether it is a constitutional system or not. In this sense, the constitution is no more than a description of the makeup or composition of a political system. It portrays the way a polity is constituted, that is, how its foundation is set forth, its first principles articulated, its character shaped, and its government organized and operated. The fact that a political system has such a constitution even if it is a formally written document does not mean it meets the standard of constitutionalism. Under the standard of constitutionalism, governments must themselves be bound by rules. To implement this standard, a constitution that reflects the principles of the constitutionalism will serve as a higher law. This higher law establishes and limits government in order to protect individual rights as well as to promote the common good. ${ }^{6}$

Instances of constitution without constitutionalism can be seen in some African states. The former Apartheid regime of South Africa had a constitution without constitutionalism. Also, General Sani Abacha of Nigeria, Idi Amin of Uganda, Jeane Bedel Bokassa of the Central Africa Empire (now Republic), Marcias Nguema of Equatorial Guinea as well as Gnasingbe Eyadema of Togo had constitutions in one form or the other. But as we all know, these so-called constitutions were devoid of constitutionalism. More importantly, though some of them could be claimed to be legal documents, they were certainly not legitimate. In fact, the so-called constitutions were instruments for terrorizing the poor and the weak, legitimating corruption and privatization of the state, and rationalizing the suffocating of civil society and subservient relationships with imperialism.

Why were these constitutions illegitimate even if legal? The truth is that they were not compacted through a truly open and democratic 
process that paid attention to the dreams, pains, and aspirations of African people, their communities, and constituencies. In fact, most of these were directly imposed constitutions or elite-driven processes that treat the people and their ideas with disrespect, if not contempt. The hallmark of this constitution is that they were never subjected to popular debates or referenda. If at any point the constitutions were subjected to public debates, such debates were often brief, carefully monitored and manipulated. The documents, either in draft or final forms, were never made available to the people. If referenda were called, the results were rigged in favour of the state and its custodians. In some cases, the reports of constitutional commissions were simply ignored after elaborate ceremonies ${ }^{6}$ aimed at diverting public attention and convincing donors and the international community that something positive was being done about democracy. In Nigeria, not only were general and presidential elections conducted without a constitution, but also the draft was never widely debated, seen or voted upon by the people. Even after the presidential election, the government continued to keep the constitution a secret and away from the Nigerian people. In an open demonstration of military arrogance and insensitivity to the popular will, the General Abdulsalami Abubakar junta refused to release the constitution even after the military ruling council spent three days "putting finishing touches" to what was supposed to be a peoples' document. In Uganda, Idi Amin turned the state to police state; the constitution remained meaningless throughout his time until his government was overthrown. Gnasingbe Eyadema of Togo was not leftout, the constitution was amended to give way for family succession. It is not surprising therefore that constitution in postcolonial Africa has never been taken as sacred. This disdainful attitude to constitution in Africa militates against its being properly employed to serve the course of democracy. A nation's constitution should be its most valued document. Preparing it is a sacred and weighty undertaking that should not be addressed in isolation of the people. Nothing is more important in the political culture and history of a nation than the constitution by which its citizens are ruled.

However, the constitution does not really occupy a pride of place in the life of the contemporary states in Africa be it under the military or civilian regime. Under a military rule, the constitution is simply ignored except where it is needed by the military elite to give a similitude of legitimacy to some policies. Almost the same attitude to the constitution is shown by political leaders in Africa. The African elites in their quest for absolute power have no qualms about subverting the constitution and manipulating it to serve the interests of small elites. ${ }^{7}$ consequently, what we have in many African countries has been constitution without constitutionalism.

\section{The effect of constitution without constitutionalism}

Political problems: They relate to actions and in-action on the part of those who are in authority. The listed items include: lack of action by government and its agencies on reported cases of act of indiscipline, corrupt government officials, political fanaticism, lack of concern for people's welfare, Conflicting rules and regulations, Poor management of resources and Lack of good government. Noncompliance of members with rules and regulations, resulting in disorderly behavior and impunity is the order of the day. Culture of violence is been instituted in the Africa system. The government survives on the control of the means of violence, thus any agitation is often met with official violence. This has affected the political society to the extent that politicians often result to the use of violence as an instrument for achieving their goals in Africa. Today the struggles for political power and control of state resources have brought instability in term of peace and social order to most African countries. In addition to this, many African were made to feel that they are second rate citizen, possibly because of their political alignment. A non-member of the ruling party becomes target for attack in the long run; many were either assassinated or incarcerated. Furthermore, those areas that fail to support the ruling party were usually left undeveloped which accounted for uneven development of many areas in Africa. No citizen who feels estranged by the government under which he lives can give to that government that instructive loyalty which is the outward and visible sign of true patriotism. ${ }^{8}$

Constitution without constitutionalism also extends its tentacle to the area of religion. Religion environment which was regarded as a sacred place of morality have been polluted because the lack constitutionalism in the state make it possible for people of diabolical mind to seize the opportunity to practice their nefarious activities. Religious as an institution supposed to teach moral and decent behavior to its adherents. According to John S. Mbiti; it is religion, more than anything else, which colours their understanding of the universe and their empirical participation in that universe, making life a profoundly religious phenomenon. To be is to be religious in a religious universe. Africans eat religiously, dance religiously, trade religiously and organize their societies religiously; but this is done in a holistic manner, without any dichotomy of the material and the spiritual. Since Africans are "incurably religious", ${ }^{9}$ then it is possible for religious institutions to serve as a vehicle for sustainable development. If African religious values promote the human good by its emphasis on the good of the community then, the modern religious value arising from religions in Africa should promote sustainable and integral development.

James D Wolfensohn ${ }^{10}$ former President of the World Bank foresaw the need for closer collaboration of the World Bank and other development institutions with religion and remarked: Religion is an omnipresent and seamless part of daily life, taking an infinite variety of forms that are part of the distinctive quality of each community. Religion could thus not be seen as something apart and personal. It is, rather, a dimension of life that suffuses whatever people do. Religion has an effect on many people's attitudes to everything, including such matters as savings, investment and a host of economic decisions. It influences area we had come to see as vital for successful development, like schooling, gender quality, and approaches to health care. In short, religion could be an important driver of change, even as it could be a break to progress. ${ }^{10}$ As a result of such dialogue there is a realization that the religious faith of people help shape their view of development and their life in general. Religion provides the unifying power that grounds the socio-political, economic, technological, cultural and moral dynamics of a culture. But in a situation where by the adherent of religion have bye bass the tenant of the religion and politicize the profane, missing religion with politics and as well as committing sacrilege because the state is lawless, then religion that supposed to teach moral and decent behaviour to its adherents now become the sources of indiscipline, lack of proper religious moral teachings, lack of fear of God, lack of commitment to religious tenets, lack of disciplined religious upbringing, hatred of rival religious or religious sects member and religious fanaticism.

Management Slacks: Poor management on the part of those at the helm of affair is another cause of indiscipline. ${ }^{11}$ Many opportunists find themselves at the corridor of power because their party is at the 
center. Many of this people are inefficient and could not deliver. Some of them often disgrace the government of the day because as poor are they are often overzealous and power drunk. The constitution is not being taking to consideration before chosen them and they see no reason why they should live by that constitution. And constitutionalism which should serve as constrain is absent in the state, what do we expect; there is bound to be maladministration of things in the state which may not pave way for the smooth running of the state.

Motivational problem: act of indiscipline, lawlessness, act of impunity is not a motivational factor for the citizen in the state instead it discourages people. Motivation is a force driving people to do things, it is a drive which is variously linked with wages, instinct, purposes, goods, desires, wants, needs, and action behind every behaviour is a motive, therefore all behaviour to motivate, it is looked at as an involvement of the physiological and social aspect of human beings. Basically, motivation means an individual needs, desire and concepts that cause him or her to act in a particular manner, our interest in motivation is basically with respect to work, it is driven towards achieving certain objectives in an organization and sometimes regarded and a tool which may be in form of financial incentive such as provision of housing scheme for staff, health scheme, recreation center and end of the year bonus, promotion. Some countries give more attention to motivational system because it always contributes to the improvement of state productivity. Here lack of motivation of all types in work within the state is listed as a cause of acts of indiscipline.

Furthermore, disregard to societal values and norms are other consequences of constitution without constitutionalism. Norms are not law but a way of life that has been adhered to by a group of people and it has been accepted and transmitted from generation to generation. Adherence to this rule is voluntary but the society has a way of sanctioning erring individuals who indulged in any of the following: Gross unfaithfulness, dishonesty, laziness, lack of commitment to organization and nation, anxiety to attain great height without works worth unnecessary haste going to nowhere, lack of trust. Sanctions by way of punishment are not expected to be different from the general mode of thought in other societies. There are many types of sanction or punishment just as we have it in other societies which are meted out to offenders. The nature of the offence should be proportional to the type of sanction or punishment meted to the offender. "Obviously, no offender escapes punishment in Yoruba (African) society while this is true, no one was made a scapegoat for the offence he has not committed; doing so amounts to incurring the wrath of the ancestors". Sanction here is expected to serve as a deterrent to others. When a society values and norms are respected and taking to cognizance, the erring individual would try as much as possible not to go against the acceptance values and norms of the society; thus individual we abstain from any unwelcome behavior that may tarnish the image of the society but constitution without constitutionalism will promote disrespect to norms and values of the society and it may not be able to perform it expected function in the society.

Military as an institution: the military as an institution in Africa had jettison their role as a professional who should maintained and secure the territorial integrity of their country but instead taken over the government they are expected to protect. They rule by decree, though they claim that it is a legal document, but certainly not legitimate. In fact, decrees are instruments for terrorizing the poor and the weak, legitimating corruption and privatization of the state, and rationalizing the suffocating of civil society and subservient relationships with imperialism. But as we all know, these so-called constitutions were devoid of constitutionalism.

Judiciary as an institution: this relate to the functioning of the legal and judicial systems in Africa. Solid judicial institution can enhance sustainable development. In a country where legal/judicial environments in consonant with the indices that can instigate development the following attribute of judicial legal content will be obvious. There will be independence of the judiciary, proper enforcement of laws, incorrupt law enforcement agents, lack of corruption in the judicial system, and fast process of trial and good welfare for the judges. In addition to this, to make the work of governance easy; the constitution of the country must be the one that we accommodate constitutionalism. Constitution with constitutionalism we enhance the sustainability of development in a country. In Africa what we have instead is constitution without constitutionalism. The functioning of the legal and judicial systems in Africa is worrisome. The legal/judicial environments in Africa are as follows: lack of independence of the judiciary, lack of proper enforcement of laws, corrupt law enforcement agents, corruption in the judicial system, very slow process of trial and lack of good welfare for the judges that made many of them to take bribe and bypass judgment.

Leadership based problem: In an ideal society, leaders are expected to be role model. But the problem with Africa has remained the issue of bad leadership. Our leaders lack discipline and the citizens are following suit. African leaders have always been known for not obeying the constitution, since the constitution itself lacks merit. The colonialists have already set in place a bad example of governance, but Africa lack good leadership that will confront this dilemma and thus take Africa out of its debilitating condition. ${ }^{12}$ Leadership is observed to be the most critical, such that many depict the continent as "a faraway place where good people go hungry, bad people run government, and chaos and anarchy are the norm." ${ }^{\prime 3}$ More so, it has been rightly observed that under "the various oppressive authoritarian regimes which Africa countries have had the misfortune to chafe under for the greater part of its post colonial history, Africans have been treated to a bastardization of constitutionalism and growing impotence of the judiciary in the face of countless acts of impunity, executive lawlessness and economic brigandage by praetorian guards that had imposed themselves on the political landscape of the nation". ${ }^{14}$ The dearth of good leadership in postcolonial Africa "is inversely proportional to the widespread poverty, not only of ideas about running the societies and states, but also the impoverishment of the populace". ${ }^{12}$ More crucially, however, the failure of the African state to properly manage its affairs is partly responsible for its inability to participate meaningfully in global processes.

This situation is further compounded by the moral decadence of the society. Unethical conducts or acts of indiscipline are the most important problem confronting most African countries. This act of indiscipline has eating deep to the fabrics of the society. The moral instinct of many have long dead to the extent that they are ready to do anything in the name of money, anybody that stand on their way could be remove at will. A lot of public funds have been spent experimenting with structures, programs and processes that could lead to moral renewal. These structures and programs have been at times built at the expense of obscuring the very content they were meant to promote. All this has arguably stemmed from the absence of a few vital ingredients necessary for moral regeneration to occur, including serious intolerance against corruption since the dire 
economic condition of the majority make social vices like corruption to thrive and politician with unfettered access to public funds are in good position to influence those who are economically impoverished to engage in political violence by inducing them with money.

The absence of constitutionalism in our constitution gives room for endemic corruption or profiteering by the ruling elites and resistance to transparency, accountability and political representations. This includes wide spread loss of popular confidence in state institutions and process. The president of the country is resisting the public declaration of his assets as the constitution and code of conduct demand. The members of national assembly, governors and all politicians receive disproportionate pay which can be described as criminal. Governors appoint more special advisers than the areas where advice is genuinely needed. No one believes anything the government says and everybody agrees that African politicians are among the most corrupt and unscrupulous in the world.

There is also a disappearance of basic state functions that serve the people, including collapsed infrastructure, total paralysis of the health sector at all levels, constant nationwide power failure and the attendant negative effects on all sectors of the economy; pervasive unemployment, thereby generating increased armed robbery cutting across all ages of our people, debilitating homelessness; retrogressive educational programmes and policies. Also using the state apparatus for agencies that serve the ruling elites, such as the security forces, presidential staff, central bank, diplomatic services, customs and collection agencies. These are currently the norm in many countries in Africa. There are more policemen protecting politicians in Africa than are available for normal police duties. The civil service has been destroyed by turning it into an instrument in the hands of politicians by making the top post political appointment. Every change in the civil service has been to increase the power of politicians over civil servants and bring them under their control to remove the valuable role they play in checking corruption and maintaining probity in public offices.

Lack of Adequate Security is another area where constitution without constitutionalism has taken toll on Africa. The machinery of law enforcement is definitely weak and as long as the police force is weak in terms of workforce and training, violence and insecurity will continue to thrive. Furthermore, where security agents are taking sides, compromising their position, violence will be inevitable because people will lose confidence in them to protect their interest and therefore take laws into their hands. The situation in most African countries is so worst to the extent that the violence is being perpetrated in the presence of military and police personnel or by the military and police personnel themselves. They aid and abet well placed individual in the society who committed political violence and go unpunished while punishing others who committed the same crime but are less powerful members of the society, thereby increasing the problem of political violence in the society. Instances of brutal killings in election period are numerous. The most tragic and disturbing aspect of the incidents is that these incidents in most cases either happened in the presence of policemen and soldiers or immediately reported to them, we just discovered that no arrest would be made and no investigations would be carried out. The scenario created from the various incidents recorded so far gave the impression that some persons were ceasing the opportunity of this unconstitutionality to destroy lives and properties of most Africans.
Lack of adherence to the rule and regulation laid down in the constitution has led to the emergence of ethnic militias in some countries in Africa, for example in Nigeria; the ethnic militias converse verbally and even openly on the state of nation. Some even went to the extent of engaging in confrontation with the state security forces in pursuance of their goals and objectives; they have different goals and aspirations. For example, the movement for the survival of Ogoni people (MOSSOP) is out to protect the interest of the Ogoni, most especially the oil exploitation and environmental degradation of their land. The Odua People's Congress (OPC) emerged in August 1994 to challenge the annulment of the June 12 presidential election won by late Chief MKO Abiola, as well as ensure the restructuring of the Nigeria federation. The Egbesu boys of Africa came up to fight the environmental degradation and exploitation of the Niger Delta by the multinational oil corporations. The failure of the police to check the menace of armed robbery in the south-east led to the formation of Bakassi Boys. The Arewa people's congress was principally set up to counter OPC which was alleged to have master minded most of the ethnic clashes in the South West. In the same view, some other countries in Africa do have rebels' movement; the group came into being as a result of one or two exploitations that could have been normalized if the government danced to the dictate of the constitution of the countries concerned. But because the ruling government failed to do the right thing the next thing for the rebel is to take arms against the ruling power. This has resulted into serious war in many countries in Africa. It happened in Liberia, Libya, Sierra Leone, Burundi, Malawi, Central Africa republic, Congo DCR and presently in Sudan. The aggrieved individuals felt marginalized and they thought that the best way to make their grievances known to the public is through violence.

In Africa, years of economic exploitation, mal-development and bad governance have continued to fan the ember of conflicts and crises in the continent. From Togo to Democratic Republic of Congo, Nigeria to Kenya and Zimbabwe to Ivory Coast, general elections have been widely disputed. The violence they spawn comes from manmade barriers on the part of smooth electoral processes. Beyond constraints of funds, manpower and other logistics, obstacles to health electoral processes emanate from the inordinate ambition of the political elite to win elections at all cost. To achieve their goal, they manipulate the constitutive and regulative instruments for credible electoral contest. All institutions and agencies of government are used by those in possession of state power and authority to remain in government. Because of the premium on power everything is mobilized to remain in power against the will of the electorates. Where the ballot box containing the preference of the governed, cannot bring about the transfer of political power from one party to another in a peaceful manner, then democracy (liberal or not) is in grave danger.

\section{Conclusion}

A political system whether it has a formal constitution or not, will reflect the principles of constitutionalism only when its powers and institutions are limited to the terms of the constitution which reflect the foundational principles of commission and trusteeship. In this regard, the constitution takes on the role of "higher law". ${ }^{15,16}$ The fact that a political system has a constitution, even if it is a formally written document does not mean that it meets the standard of constitutionalism. Under the standard of constitutionalism, governments must themselves be bound by rules. To implement this standard, a constitution that reflects the principles of constitutionalism 
will serve as a higher law. This higher law establishes and limits government in order to protect individual rights.

So, the value of a constitution with constitutionalism lies in the fact that it gives meaning to the relationship between the state and the citizens and this invariably brings about the much needed social order. Thus, the foundation of a sustainable social order in any society is based on the cordial relationship between the state and the citizens as established by the constitution. When the enabling environment is visible, there will be an efficient social contract. Mueller recognizes the significant function of the constitution when he describes it as "a form of social contract among citizens defining the rules within which the society functions". ${ }^{17} \mathrm{~A}$ further look reveals that social contract is transactional. It provides a situation, where people are more tolerant of one another to live happily. It is a transformational agreement built on trust, providing a place where citizens can become fully human by having an identity that is rooted in respect for others. In this regard, any constitution without constitutionalism may create a disconnection between the state and the citizens, making it increasingly difficult for the citizens to rely on the state. Thus, the society becomes an arena of various conflicts and promotion of common good is thereby sacrificed. For Africa to move forward there is the need to move toward constitution with constitutionalism. The government and its agencies should take action on reported cases of act of indiscipline, corrupt government officials, political fanaticism, lack of concern for people's welfare, Conflicting rules and regulations and Poor management of resources. The government take necessary action on any person that fail to comply with rules and regulations that may result in disorderly behavior and impunity within the state.

\section{Acknowledgments}

None.

\section{Conflict of interest}

Author declares there is no conflict of interest.

\section{References}

1. Jubril BM. Concept, Theory and Evolution of constitution Constitutionalism and National Question. Lagos: Centre for Constitutionalism and Demilitarisation. 2000. p.16
2. De Smith and Rodney Brazier. Constitutional And Administrative Law. London and New York: Penguin Book. 1998. p. 6-7.

3. Reynoids NB. The Ethnical Foundations of Constitutional Order: A Conventionalist Perspective. Const Pol Econ. 1993;4(1):79-95.

4. William ES. Constitutionalism. In An Age Of Speed. Const Comment. 2002.

5. Fombad MC. Challenge to Constitutionalism and Constitutional Rights in Africa and the Enabling Role of Political Parties: Lessons and Perspectives from Southern Africa. Am J Comp. 2007;55(1):1-45.

6. Rothbard MN. For a New Liberty: The Libertarian Manifesto. 1978. p. 48.

7. Newswatch Magazine. 2001.

8. Aro I. Religion and Ethnicity as a means of maintaining the status Quo in Nigeria Politics. In religion and National Unity. Sam Babs Mala, editor. Ibadan: Orita Publication. 1988. p. 28.

9. John S Mbiti. African Religions and Philosophy. London: Heimemann Educational Books Ltd. 1969. p. 262.

10. James D Wolfensohn. "Forward." Gerrie Ter Haar, editor. Religion and Development. 2007. p. xvii.

11. Ogundele OJK, Opeifa AZ. Importance of ethicaleducation in economic and social reconstruction. Nigerian Journal of Curriculum and Instruction. 2004;2(2):164-169.

12. Afolayan A. "Poverty as statecraft: preliminary reflections on African Leadership. ” In: Afolayan, Supra A, editors. In Lumina. 2009;20(2):1.

13. Alex Thomson. An Introduction to African Politics. 2nd ed. London and New York: Routledge; 2002.

14. Oyebode A. The Challenges of Building a Virile Democratic Nation in Critical Issues on Sustainable Democracy and Development: Nigerian Perspective. Leadership Watch. 2005. p. 49-61.

15. Mbiti JS. African Religions and Philosophy. London: Heinemann, 1980. p. 290 .

16. Buchanan JM. What Should Economist Do? Indianapolis: Liberty Press. 1979. p. 9.

17. Ihonvbere JO. Towards a New Constitutionalism in Africa. CDD Occasional Paper Series. 2000;4:10-11. 